\title{
Masalah Utama Ekonomi Indonesia: Tantangan bagi Rezim Pemerintahan 2004-2009
}

\author{
Edy Suandi Hamid
}

The main problem of Indonesian economy for the next five years is not so different from that of nowadays. The problems that mentioned above are dealing with how to overcome poverty, to increase economic growth, to enlarge vocation, to build human resources., and besides, to decrease corruption. To solve those problems of this nation does not enough only a period of government and using abstract jargons. For that reason, next regime needs a clear cut explanation, planned and listed of economic agendas. So that, these economic agendas can show program that observed and clear targets.

emilihan Umum anggota legislatif 2004, yang sebelumnya dikhawatirkan mengalami gangguan-gangguan serius, ternyata berlangsung dengan aman dan relatif lancar. Walaupun diberitakan terjadi berbagai kekurangan, kecurangan, dan ketidakpuasan atas proses dan pelaksanaan Pemilu itu sendiri, namun secara umum Pemilu legislatif 2004 dapat dikatakan cukup baik. Forum Rektor dan pemantau Pemilu dari Uni Eropa juga menilai secara umum proses pesta demokrasi ini berlangsung dengan relatif aman, tentram, dan jujur. Penolakan terhadap hasil Pemilu sempat dilakukan oleh aliansi tokoh-tokoh parpol, namun ini hanya sebatas manuver politik yang pada akhirnya hilang dengan sendirinya.

Sebagaimana diketahui, hasil akhir dari Pemilihan Umum ini telah menghasilkan tujuh partai politik yang lolos dari threshold atau memperoleh suara di atas tiga persen dari total suara pemilih yang sah. Parpol- parpol tersebut adalah Partai Golkar, Partai Demokrasi Indonesia Perjuangan (PDIP), Partai Kebangkitan Bangsa (PKB), Partai Persatuan Pembangunan (PPP), Partai Demokrat (PD), Partai Keadilan Sejahtera (PKS) dan Partai Amanat Nasional (PAN). Hasil pemilu legislatif ini cukup menggambarkan terjadinya perubahan peta kekuatan politik di tanan air. Kekuatan partai besar masa Orde Baru, seperti PDIP, Golkar, dan PPP, secara kuantitif merosot. Namun demikian, dari sisi peringkat, Golkar mengalami kenaikan dari peringkat dua pada tahun Pemilu 1999 menjadi peringkat pertama pada Pemilu 2004.

Kejutan yang menarik dari Pemilu 2004 adalah munculnya kekuatan baru dalam elit perpolitikan Indonesia, yaitu Partai Demokrat dan Partai Keadilan Sejahtera. Berbagai perubahan ini telah menimbulkan harapan dari masyarakat untuk. perbaikan di berbagai bidang kehidupan di tanah air. Perubahan komposisi țasil Pemilu legislatif 
ini tidak bisa dilepaskan dari kekecewaan masyarakat Indonesia atas kinerja pemerintahan periode 1999-2004. Era yang semula diharapkan merupakan era reformasi yang menjanjikan berbagai perubahan, ternyata jauh dari harapan. Keinginan untuk hidup dalam negeri yang semakin adil dạn makmur tidak terjadi. Bahkan sebaliknya. Misalnya, indikator kinerja yang terkait dengan bidang ekonomi sejak "era reformasi", masih jauh di bawah kinerja Orde Baru. Praktik-praktik yang menurunkan daya saing nasional berupa korupsi, kolusi, dan nepotisme (KKN) semakin meluas. Jika pada waktu lalu KKN terkonsentrasi di eksekutif, dan juga yudikatif, sekarang meluas ke legislatif.' Sampai saat ini Indonesia masuk negara peringkat atas yang paling korup di Asia dan di dunia. Berbagai kasus di tanah air menunjukkan banyaknya penggunaan anggaran belanja publik dengan rekayasa nama pos-pos pengeluaran yang canggih, sehingga pengeluaran tersebut menjadi legal.

\section{Egoisme Kekuasaan dan Masalah Ekonomi}

Pemilihan Umum secara formal merupakan sarana demokratis untuk membangun dan mengeluarkan bangsa indonesia dari berbagai persoalan yang dihadapinya. Dengan demikian, siapa pun yang menjadi pemenang dalam Pemilihan Umum legislatif dan Pemilihan Umum Eksekutif (Presiden/Wapres) mereka mempunyai. misi yang sama, yakni memecahkan problematik bangsa. Hal ini seharusnya menjadi platform bersama parpol-parpol tersebut. Dengan melihat apa yang disampaikan oleh partai politik selama kampanye, maka sulit ditemui partai yang benar-benar memasarkan program ekonominya secara jelas untuk menge- luarkan perekonomian dari krisis tersebut. Hampir tidak ada partai politik yang mampu menjelaskan program ekonominya dengan rinci sampai tingkat operasionali-sasinya. Program yang ada masih tinggal dalam dataran jargon. ${ }^{2}$ Partai-partai hanya berlomba-lomba menyampaikan statement umum, melalui retorika politik dengan isu untuk keluar dari krisis, menekan pengangguran, mengurangi kemiskinan, atau mengembangkan ekonomi rakyat. Namun yang disampaikan lebih pada sesuatu yang bersifat permukaan. Bagaimana langkah atau kebijakan detail untuk mencapai sasaran-sasaran pembangunan itu, dan bagaimana tahapannya, masih belum muncul. Padahal sasaran yang ingin dicapai tersebut merupakan target besar yang bukan saja tidak bisa diselesaikan satu-dua tahun, namun dalam satu periode pemerintahan pun belum akan selesai.

Adanya egoisme kekuasaan telah mengakibatkan para elit politik berusaha mengedepankan kepentingannya yang berakibat tidak menguntungkan bagi kepentingan bangsa secara keseluruhan. Munculnya "gerakan" penolakan atas hasil Pemilu 2004 yang dilakukan aliansi parpol yang lalu merupakan contoh egoisme elit politik yang dapat menimbulkan ketidakpastian di tanah air. Dari sisi ekonomi, misalnya, manuver penolakan tersebut mengakibatkan para pelaku ekonomi sangat berhati-hati untuk melaksanakan aktivitas bisnisnya di Indonesia. Demikian pula

'Edy Suandi Hamid, Ketimpangan Fiskal Vertikal dan Formula Altematif Dana Alokasi Umum disertasi pada Program Studi Ilmu Ekonomi Pasca Sarjana UGM, Yogyakarta 2003.

${ }^{2}$ Chatib Basri, Paradoks Platform Ekonomi Partai Politik, dalam KOMPAS, 8 Maret 2004. 
menjelang pemilihan presiden/wakil presiden, awalnya yang diperbincangkan parpol lebih pada persoalan pembagian kekuasaan, dengan mencari koalisi yang bisa mengantarkan mereka pada puncak kekuasaan, dan belum didasari pada pemikiran untuk membawa bangsa ini keluar dari jurang krisis, atau untuk meluruskan jalannya reformasi.

Dari perspektif ekonomi, masalahmasalah besar yang dihadapi bangsa indonesia saat ini antara adalah: (1) tingginya angka kemiskinan dan pengangguran; (2) laju pertumbuhan ekonomi yang masih rendah; (3) rendahnya investasi, baik domestik maupun asing; (4) rendahnya daya saing produk Indonesia di pasar internasional; (5) tingkat korupsi yang tinggi; (6) ketimpangan yang tinggi antara unit-unit usaha besar dan kecil; dan (7). Di samping itu, sebagian masalah di atas, juga tidak bisa dilepaskan dari aspek sumber daya manusia, yang kualitasnya masih relatif rendah. Hal ini bisa dilihat dari indikator Indeks Pembangunan Manusia (Human Development Index), yang peringkat indonesia berada pada posisi yang relatif rendah, yakni peringkat 112 dari 175 negara pada tahun 2003) (UNDP, 2003). Berbagai problematik ekonomi utama yang dihadapi pemerintahan baru sebenarnya tidak berbeda sama saja dengan pemerintahan sebelumnya. Dengan kata lain, sebagaimana dikemukakan Rowter (2004): "Apa pun komposisi suara dalam pemilu legislatif, dan siapun yang menjadi presiden mendatang, tantangan kebijakan ekonomi sudah cukup jelas".

Salah satu masalah utama bidang ekonomi tersebut adalah berkaitan dengan laju pertumbuhan ekonomi yang rendah. Sejak krisis ekonomi melanda tahun 1997, pertumbuhan ekonomi masih sangat lamban, dengan laju pertumbuhan di bawah
$5 \%$ per tahun. Setelah mengalami laju pertumbuhan negatif sebesar lebih dari $13 \%$ tahun 1998, pada tahun selanjutnya perekonomian Indonesia mencoba bangkit, dan mengalami pertumbuhan positif. Masalahnya adalah laju pertumbuhan tersebut belum bisa kembali normal seperti sebelum tahun 1997, di mana laju pertumbuhan perekonomian rata-rata mencapai $7 \%$ per tahun. Tahun 1997 perumbuhan ekonomi hanya $5 \%$, dan pada puncak krisis tahun 1998 pertumbuhan negatif $-13,7 \%$. Pertumbuhan tahun berikutnya selalu pada kisaran rendah, yakni $0,96 \%$ (999), $4,92 \%$ (2000), 3,45\% (2001), dan $3,8 \%$ pada tahun 2002 . Sedangkan laju pertumbuhan ekonomi tahun lalu hanya $4,1 \%$, dan tahun ini diperkirakan bisa meningkat lagi menjadi sekitar $4,5 \%$. Namun demikian, dengan peningkatan yang masih relatifkecil, telah mengakibatkan pula pada rendahnya penciptaan kesempatan kerja di tanah air, sehingga akumulasi pengangguran meningkat sangat cepat.

Dengan melihat masalah-masalah tersebut, maka siapapun yang berkuasa memang tidak mudah baginya untuk secara cepat dapat menyelesaikan masalah ekonomi di tanah air. Walaupun ada janjijanji dalam kampanye pemilu yang menyatakan akan menciptakan kesempatan kerja besar-besaran, atau dengan segera menghapuskan korupsi, misalnya, namun hal ini susah untuk dapat diwujudkan dalam tempo singkat, atau bahkan dalam satu periode pemerintahan. Satu hal yang diharapkan dari pemerintahan baru adalah komitmennya yang disertai agenda aksi yang jelas dan terukur untuk secara serius menjawab berbagai persoalan tersebut. Artinya, ketika mereka ingin menghapuskan pengangguran, misalnya, maka kebijakan-kebijakan ekonomi haruslah di arahkan pada investasi-investasi 
yang secara nyata bisa menciptakan kesempatan kerja baru secara besarbesaran. Ini berarti bukan hanya investasi skala besar yang didorong, melainkan investasi kecil dan menengah, yang dengan nilai investasi sedikit bisa menyerap tenaga kerja dalam jumlah besar.

\section{Masalah Kemiskinan .}

Sebagaimana dikemukakan sebelumnya, masalah kemiskinan ini merupakan persoalan mendesak yang dihadapi perekonomian Indonesia. Dengan ukuran Badan Pusat Statistik (BPS), yang lebih didasarkan pada pendekatan pendapatan atau konsumsi tersebut, tahun 2002 jumlah penduduk miskin di tanah air menapai 38.4 juta jiwa atau $18,2 \%$ dari total penduduk. Angka ini jauh lebih kecil dibandingkan pada tahun 1976 yang mencapai 54,2 juta $(40,1 \%)$, namun lebih tinggi dibandingkan angka sebelum krisis ekonomi (1996) yang "hanya" 22,5 juta jiwa. Pada saat puncak krisis ekonomi terjadi (1998) tingkat kemiskinan ini dilaporkan mencapai 79 juta jiwa (49\%). Namun ini hanyalah angka kemiskinan yang sifatnya sementara (transient poverty), yang kemudian secara tajam menurun kembali.

Angka kemiskinan 2002 yang mencapai 38,4 juta tersebut secara absolut merupakan bilangan yang cukup besar, ekuivalen dengan dua kali lebih banyak dibandingkan dengan total penduduk Malaysia ataupun Australia, atau lebih dua belas kali lipat jumlah penduduk Singapura. Krisis ekonomi yang terjadi sejak 1997 memberikan kontribusi terjadinya peningkatan angka kemiskinan ini. Lesunya kegiatan perekonomian, telah menurunkan pula peluang memperoleh pendapatan, di samping adanya pekerja yang kehilangan pekerjaannya, atau angkatan kerja baru yang semakin banyak tidak terserap di pasar kerja sehingga menjadi penganggur. Namun demikian pengangguran bukanlah pemberi kontribusi terbesar dalam tingkat kemsikinan. Sebagai gambaran suatu studi di kota Yogyakarta (FE Uil, 1999) menunjukkan bahwa pengangguran hanya memberikan kontribusi sebanyak $3,32 \%$ saja dari total kemiskinan. Ini mengindikasikan bahwa masyarakat miskin tersebut sebagian besar mempunyai pekerjaan, namun pendapatannya sangat kecil, atau bekerja dengan waktu kerja di bawah jam kerja normal (underemployment).

Pengangguran hanyalah salah satu faktor penyebab kemiskinan. Penyebab lainnya adalah karena keterbatasan sumber daya yang dimiliki suatu masyarakat, baik sumber daya alam maupun manusianya. Untuk Indónesia, yang secara relatif kaya sumber daya alam, ini bukanlah suatu faktor penyebab: : Hal ini terjadi karena ketidakmampuan masyarakat dalam memanfaatKan sumber daya alam yang tersedia tersebut secara optimal, baik karena keterbatasan kemampuan maupun karena kebijakan yang keliru dalam mengelola sumber daya alam tersebut. Faktor lain yang bisa dilihat secara mikro, adalah karena keterbatasan kepemilikan alat-alat produksi, seperti tanah dan modal; sarana dan prasarana yang terbatas; kebijakan yang bias sektor moderen/perkotaan/atau usaha besar; rendahnya pendidikan dan ketrampilan; atau faktor budaya yang menyebabkan masyarakat terjebak dalam kultur kemiskinan.

Untuk menanggulangi kemiskinan ini maka peran pihak eksternal, di samping adanya tekad kuat dari si miskin sendiri, sangat dibutuhkan untuk membantu menanggulangi kemiskinan tersebut. Kebijakan pemerintah yang berpihak pada 
si miskin ini menjadi sesuatu keharusan jika ingin menghapus kemiskinan. Lingkaran kemiskinan (vicious cyrcle) yang terjadi sulit diputus tanpa intervensi dari pihak eksternal. Namun yang sering terjadi adalah justru sebaliknya. Kebijakan pemerintah justru menimbulkan peningkatan kemiskinan, sehingga muncul kritikan kepada pemerintah yang gagal dalam menanggulangi kemiskinan dengan adagium "They are poor because poor policy". Kebijakan pemerintah lebih berpihak pada yang besar. Pemerintah sangat enteng membantu pelaku ekonomi besar, atau mereka yang mempunyai akses pada pengambil keputusan dengan dalih untuk mendorong atau untuk pemulihan perekonomian dari krisis. Untuk membantu bank-bank yang collapse dan tidak mampu semua penduduk miskin Indonesia saat ini, maka masing-masing akan mendapatkan sekitar 16,19 juta per kepala. Ini tentu merupakan modal yang berarti bagi si miskin untuk dapa langsung "diangkat" dari lembah kemiskinan. Oleh karena itu, pemerintahan yang akan datang harus tidak mengulangi kesalahan yang sama dengan membuat kebijakan-kebijakan yang berpotensi meningkatkan kemiskinan dan berpihak pada ekonomi kuat,

Pada masa pemerintahan rezim Orde Baru sebenarnya usaha untuk mengurang kemiskinan ini sudah berhasil secara cukup signifikan, yang tercermin dari terus menurunnya jumlah penduduk miskin tersebut sebagaimana ditunjukkan dalam Tabel 1.

Tabel 1. Garis Kemiskinan dan Penduduk Miskin di Indonesia 1976-2002

\begin{tabular}{|c|c|c|c|c|c|c|c|c|c|c|}
\hline \multirow[b]{2}{*}{ Tahun } & \multicolumn{2}{|c|}{$\begin{array}{c}\text { Garis } \\
\text { Kemiskinan } \\
\text { (Rupiah/kapital } \\
\text { bulan) }\end{array}$} & \multicolumn{4}{|c|}{ Persentase Penduduk Miskin } & \multicolumn{4}{|c|}{ Jumlah Penduduk Miskin (Juta orang) } \\
\hline & Kota & Desa & Kota & Desa & Total & $\begin{array}{c}\% / 4 \\
\text { Peruba } \\
\text { han }\end{array}$ & Kota & Desa & Total & $\begin{array}{c}\text { Perubahan } \\
\text { Absolut } \\
\text { (juta) }\end{array}$ \\
\hline J976 & 4.552 & 2.849 & 30,8 & 40,4 & 40,1 & - & 10,0 & 44,2 & 54,2 & - \\
\hline 1978 & 4.969 & 981 & 30,8 & 33,4 & 33,3 & $-6,8$ & 8,3 & 38,9 & 47,2 & $-7,0$ \\
\hline 1980 & 6,831 & 4.449 & 29,0 & 28,4 & 28,6 & $-4,7$ & 9,5 & 32,8 & 42,3 & $-4,9$ \\
\hline 1981 & 9.777 & 5.877 & 28,1 & 26,5 & 26,9 & $-1,7$ & 9,3 & 31,3 & 40,6 & $-1,7$ \\
\hline 1984 & 13.730 & 7.746 & 23,1 & 21,2 & 21,6 & $-5,2$ & 9,3 & 25,7 & 35,0 & 5,6 \\
\hline 1987 & 17.381 & 10.294 & 20,1 & 16,1 & 17,4 & $-4,2$ & 9,7 & 20,3 & 30,0 & 5,0 \\
\hline 1990 & 20.614 & $\llbracket 3.295$ & 16,8 & 14,3 & 15,1 & $-2,3$ & 9.4 & 17,8 & 27,2 & $-2,8$ \\
\hline 1993 & 27.905 & {$[8.244$} & 13,4 & 13,8 & 13,7 & $-1,4$ & 8,7 & 17,2 & 25,9 & $-1,3$ \\
\hline 1996 & 38.246 & 27.413 & 9,7 & 12,3 & 11,3 & $-2,3$ & 7,2 & 15,3 & 22,5 & $-3,4$ \\
\hline $1996 \mathrm{a}$ & 42.032 & 31.366 & 13,6 & 19,9 & 17,7 & - & 9,6 & 24,9 & 34,5 & - \\
\hline Des 1998 & 96.959 & 72.780 & 21,9 & 25,7 & 24,2 & 6,5 & 17,6 & 31,9 & 49,5 & 15,0 \\
\hline Feb 1999 & 92,409 & 74.272 & $\begin{array}{r}19,5 \\
(19,4)\end{array}$ & $\begin{array}{r}26,1 \\
(26,0)\end{array}$ & $\begin{array}{r}23,5 \\
(23,4)\end{array}$ & -0.7 & $\begin{array}{r}15,7 \\
(15,6)\end{array}$ & $\begin{array}{r}32,7 \\
(32,4)\end{array}$ & $\begin{array}{r}48,4 \\
(48,0)\end{array}$ & $-1,1$ \\
\hline Ags 1999 & 89.845 & 69.420 & $\begin{array}{r}15,1 \\
(15,0)\end{array}$ & $\begin{array}{r}20,2 \\
(20,0)\end{array}$ & $\begin{array}{r}18,2 \\
(18,0)\end{array}$ & $-5,3$ & $\begin{array}{r}12,4 \\
(12,3)\end{array}$ & $\begin{array}{r}25,1 \\
(24,8)\end{array}$ & $\begin{array}{r}37,5 \\
(37,1)\end{array}$ & $\cdot 10.9$ \\
\hline $2000^{\circ}$ & 91.632 & 73.684 & 14,58 & 22,14 & 18,95 & 4,1 & 12,1 & 25,2 & 37,3 & $-0,2$ \\
\hline $2001^{\circ}$ & 100.011 & 80.382 & 9,76 & 24,95 & 18,40 & $-2,9$ & 8.5 & 28,6 & 37,1 & $-0,2$ \\
\hline $2002^{*}$ & 130.499 & 96.512 & 14,46 & 21,10 & 18,20 & $-1,1$ & 13.3 & 25,1 & 38,4 & 1,3 \\
\hline
\end{tabular}

Sumber: Mubyarto (2004: 11)

menunaikan kewajibannya, misalnya, pemerintah harus menanggung beban dana rekapitalisasi perbankan sebanyak $R p 650$ triliun. Angka ini, jika didistribusikan kepada
Pada waktu lalu harapan untuk menghilangkan jumlah penduduk miskin

${ }^{3}$ Mubyarto, Teknokrat dan Ekonomi Pancasila, PUSTEP UGM, Yogyakarta 2004. 
absolut ini sudah mengemuka. Program Inpres Desa Tertinggal, misalnya, secara kongkret juga diarahkan untuk menghapuskan kemiskinan yang banyak terjadi di pedesaan. Namun ketika program ini sedang bergulir, krisis ekonomi sudah menerpa, dan krisis politik-keamanan yang kemudian melanda Indonesia telah mengakibatkan semakin sulitnya kehidupan ekonomi masyarakat. Akibatnya, penduduk miskin pun bertambah banyak.

Gambaran mengenai meningkatnya penduduk miskin ini merupakan tantangan yang harus dijawab oleh pemerintahan baru. Pada masa pemerintahan Pada masa kepemimpinan Presiden Megawati (20012004) dengan PDIP yang menslogankan sebagai "Partai Wong Cilik", ternyata tidak mampu mengurangi jumlah penduduk miskin ini. Hal ini terjadi karena usaha riil untuk mengurangi jumlah penduduk miskin ini belum nampak, dan penanganannya masih bersifat umum dengan program-program yang berjalan secara as usual. Padahal, kemiskinan ini harus ditangani secara khusus, terpadu antar departemen, dan disertai dengan program kongkret yang langsung bisa menyentuh dan mengangkat kehidupan penduduk miskin tersebut, baik yang ada di perdesaan maupun perkotaan. Sejauh mana pemerintahan baru nanti mampu menurunkan jumlah penduduk miskin, sengat tergantung pada usaha serius yang khusus di arahkan pada si miskin ini. Bantuan peningkatan ketrampilan, modal, atau pembangunan infrastruktur di daerah tepencil, merupakan langkah yang diharapkan bisa menjadi instrumen mengurangi kemiskinan tersebut.

\section{Pengangguran}

Semakin bertambahnya jumlah penduduk telah meningkatkan jumlah angkatan kerja di Indonesia. Pertambahan angkatan kerja ini secara teoritik sangat diperlukan untuk mendukung perkembangan ekonomi. Pertambahan angkatan kerja berarti meningkatnya faktor produksi, yang secara teoritik berarti terjadinya pergeseran kurva kemungkinan produksi (production possibility curve) ke atas, yang berarti bertambahnya kapasitas produksi nasionai. Namun demikian dalam kenyataannya hal itu tidak selalu terjadi. Artinya, tidak semua faktor produksi itu bisa digunakan secara penuh. Pertambahan angkatan kerja yang ada tidak bisa terserap semuanya pasar tenaga kerja kita. Berbagai perhitungan menunjukkan setiap tahun pertambahan angkatan kerja mencapai 2,5-2,75 juta orang. Di sisi lain, daya serap dari pasar kerja hanya sekitar 1,2-1,6 juta jiwa. Dengan demikian, setiap tahun terjadi tambahan pengangguran terbuka baru sekitar lebih dari satu juta jiwa. Padahal, untuk tahun 2003 saja pengangguran terbuka sudah mencapai 10,13 juta jiwa, dan setengah menganggur sekitar 40 juta orang.

Dengan kondisi yang ada sekarang. maka akumulasi angka pengangguran terbuka dan setengah menganggur di Indonesia kecenderungannya secara absolut semakin besar. Walaupun tidak semua penganggur ini adalah miskin, namun dalam jangka panjang hal ini akan menambah beban ekonomi, dan bisa menimbulkan ledakan masalah sosial di tanah air. Para penganggur yang sama sekali tidak mempunyai sumber pendapatan, akan menjadi sumber masalah sosial dalam masyarakat. Berbagai kejahatan dan tindak kriminal yang terjadi, umumnya dilakukan oleh para penganggur, dan yang setengah menganggur, di samping juga oleh yang bekerja keras namun pendapatannya tidak memadai.

Pandangan yang sering muncul untuk mengatasi pengangguran ini adalah dengan 
cara meningkatkan pertumbuhan ekonomi menjadi lebih tinggi lagi. Secara empirik ditunjukkan bahwa setiap pertumbuhan ekonomi $1 \%$ bisa meningkatkan kesempatan kerja sebesar 400 orang. Dengan demikian, laju pertumbuhan ekonomi sebesar $4 \%$ seperti yang terjadi saat ini hanya bisa menciptakan kesempatan kerja baru sebanyak 1,6 juta orang, atau di bawah jumlah pertambahan angkatan kerja. Dengan asumsi statistik, maka saat ini dibutuhkan pertumbuhan ekonomi sekitar $7 \%$. Untuk mendukung pertumbuhan ekonomi tersebut, maka diperlukan peningkatan investasi, baik domestik maupun asing dalam jumlah besar. Padahal, saat ini investor masih sungkan menanamkan modalnya di Indonesia, baik disebabkan faktor ekonomi maupun faktor nonekonomi. Dengan pola pikir, maka muncul kesimpulan bahwa bertambahnya pengangguran ini sebagai akibat investasi yang mengalami stagnasi.

Pandangan perlunya percepatan pertumbuhan ekonomi dan investasi untuk mengatasi pengangguran tersebut, agaknya juga merupakan pandangan dari pengambil kebijakan ekonomi di Indonesia. Akibatnya, karena investasi sulit, pemerintah seakan menyerah dengan menerima secara pasrah perkembangan pengangguran yang terus bertambah tersebut. Pemerintah yang akan datang pun jika tetap berpegang pada paradigma pembangunan yang sama, akan terjebak pada kondisi status quo.tersebut. Padahal asumsi hubungan antara investasi, pertumbuhan ekonomi, dan pengangguran tersebut bisa diubah.

Anggapan setiap pertumbuhan ekonomi $1 \%$ bisa meningkatkan penyerapan kesempatan kerja baru sebanyak 400 ribu orang, bukanlah sesuatu yang given. Hal itu terjadi kalau mesin pertumbuhan ekonomi diserahkan kepada unit-unit usaha skala besar, bukan pada usaha kecil-menengah. Unit-unit usaha besar ini memang membutuhkan investasi yang besar untuk dapat menciptakan kesempatan kerja baru. Menurut data dari Kementerian Usaha Kecil dan Menengah (UKM) (2004), rata-rata unit usaha besar memerlukan investasi sebesar Rp 91,4 miliar. Data ini menunjukan bahwa dengan hanya mengandalkan unit usaha skala besar yang sangat padat modal, pada saat ini akan sulit bisa mengatasi masalah pengangguran di tanah air, baik itu pengangguran terbuka maupun setengah menganggur.

Upaya pengurangan pengangguran membutuhkan perubahan paradigma pembangunan yang tidak dapat pada skala usaha besar (padat modal), melainkan sebaliknya untuk lebih memberi kesempatan lebih banyak pada unit usaha kecil, termasuk usaha mikro, dan menengah. Berbeda dengan skala usaha besar, unit usaha kecil rata-rata hanya membutuhkan Rp 1,5 juta per unit usaha per tahun, dan . untuk usaha menengah adalah $R p$ 1,3 miliar per usaha per tahun. Jadi, jika uniț usaha besar dengan investasi $R p 91,4$ miliar hanya bisa menciptakan satu unit usaha, maka dengan investasi yang sama bisa diciptakan 61 ribu unit usaha baru pada di usaha kecil. Banyaknya unit usaha yang bisa diciptakan dengan investasi terbatas di usaha kecil, mencerminkan juga banyaknya kesempatan kerja baru yang dapat diciptakannya jika unit usaha tersebut didorong untuk tumbuh dan berkembang.

Dengan data sederhana di atas dapat dikemukakan bahwa unit usaha kecil dan menengah bisa lebih diharapkan untuk mengatasi masalah pengangguran ini. Namun demikian hal itu memerlukan perubahan paradigma dalam pembangunan di tanah air, dari orientasi usaha bèsar ke kecil menengah, Namun demikian ini tidak 
berarti bahwa skala besar dihambat pertumbuhannya. Unit usaha besar tetap penting untuk menopang pertumbuhan ekonomi. Namun usaha kecil perlu lebih diperhatikan dibandingkan masa sebelumnya. Dorongan ini dalam bentuk memberi peluang usaha lebih besar, bantuan permodalan, pemasaran, dan sebagainya.

\section{Indeks Pembangunan Manusia}

Problematik perekonomian Indonesia jelas tidak bisa dilepaskan dari masalah pembangunan manusianya yang relatif tertinggal kualitasnya. Salah satu ukuran pembangunan yang banyak digunakan di dunia saat ini adalah indikator Indeks Pembangunan Manusia (Human Development index). Indikator ini dikembangkan UNDP sejak tahun 1990. Variabel yang digunakan oleh UNDP dalam penetapan Indeks Pembangunan Manusia adalah usia harapan hidup (life of expectancy), tingkat melek huruf (iiteracy rate), lama sekolah (years of schooling), dan pendapatan per kapita yang disesuaikan dengan paritas daya beli (purchasing power parity) ${ }^{4}$ Dengan menggunakan indikator ini, Indonesia ternyata masih tertinggal dibandingkan dengan banyak negara lain di dunia, termasuk di ASEAN. Padahal pembangunan pada hakekatnya merupakan pembangunan manusia, sehingga aspek ini perlu mendapaixan priontas dalam menyusun program pembangunan itu sendiri. Laporan Pembangunan Manusia dari United Nations Development Programme (UNDP) menunjukkan Indeks Pembangunan Manusia (Human Development Index) Indonesia tahun 1999 berada pada peringkat 105 dari 174 negara yang disurvei, kemudian menurun menjadi peringkat 110 dari 173 negara pada tahun 2002. Pada tahun 2003 peringkat ini kembali merosot ke peringkat 112 darj 175 negara Posisi Indonesia berada di bawah negara-negara sepert Suriname, Tunisia, Sri Lanka, ataupun Vietnam (Tabel). Rendahnya IPM ini telah membuat rendahnya daya saing Indonesia di pasar global.

Rendahnya IPM Indonesia ini tidak bisa dilepaskan dari rendahnya alokasi anggaran untuk bidang tersebut. Misalnya, dapat dilihat darj pengeluaran pemerintah yang dapat berpengaruh pada kualitas SDM, yakni untuk pendidikan dan kesehatan, porsinya sangat kecil $(1,4 \%$ dari GNP dan $0,6 \%$ dari GDP), lebih rendah dibandingkan Pakistan (2,7\% dan 0,8\%), Sri Lanka $(3,4 \%$ dan $1,4 \%)$, dan China $(2,3 \%$ dan $0,7 \%) .^{5}$ Padahal, PDB per kapita Indonesia lebih tinggi dibandingkan dengan penduduk negara-negara tersebut

Dalam konteks untuk mendukung pembangunan ekonomi, pembangunan manusia merupakan faktor yang dominan. Berbagai studj empirik menunjukkan hal tersebut. Penelitian Habibi dkk di Argentina ${ }^{6}$ menemukan aspek pembangunan manusia merupakan landasan bagi upaya peningkatan kesejahteraan, yang berpengaruh pada pertumbuhan dan pemerataan. Pengaruh langsung pembangunan manusia terhadap pertumbuhan ekonomi dapat dilihat pada hasil penelitian Bank Dunia (1993) dan Bank Pembangunan Asia (ADB, 1997). Ditemukan bahwa tingkat melek huruf yang

+ Michael Todaro, Economic Development. edisi ketujuh. Addison-Wesley, England 2000.

${ }^{5}$ UNSFIR (United Nations Support Facility for Indonesian Recovery), Indonesia: The National Human Development Report 2000, Jakarta:UNSFIR

${ }^{6}$ Nadir Habibi et. al, "Decentralization in Argentina", Economic Growth Center Discussion Paper Series, Paper No. 525, New Heaven:Economic Growth Center Yale University 2001 
Tabel 2: Indeks Pembangunan Manusia 2003

\begin{tabular}{|c|c|c|c|}
\hline HDI rank & \multicolumn{2}{|c|}{ HDi rank: } & HOI rank \\
\hline High human development & Mèdium hum & development & Low human development \\
\hline $\begin{array}{l}\text { 1. Norway } \\
\text { 2. Iceland } \\
\text { 3. Sweden } \\
\text { 4. Australia } \\
\text { 5. Netherlands } \\
\text { 6. Belgium } \\
\text { 7. United States } \\
\text { 8. Canada } \\
\text { 9. Japan } \\
\text { 10. Switzerland } \\
\text { 11. Denmark } \\
\text { 12. Ireland } \\
\text { 13. United Kingdom } \\
\text { 14. Finland } \\
\text { 15. Luxemborg } \\
\text { 16. Austria } \\
\text { 17. France } \\
\text { 18. Germany } \\
\text { 19. Spain } \\
\text { 20. New Zealand } \\
\text { 21. Italy } \\
\text { 22. Israel } \\
\text { 23. Portugal } \\
\text { 24. Greece } \\
\text { 25. Cyprus } \\
\text { 26. Hong Kong,China } \\
\text { 27. Barbados } \\
\text { 28. Singapore } \\
\text { 29. Slovenla } \\
\text { 30. Korea.Rep.of } \\
\text { 31. Brunei Darussalam } \\
\text { 32. Czech Republic } \\
\text { 33. Malta } \\
\text { 34. Argentina } \\
\text { 35. Poland } \\
\text { 36. Seychelles } \\
\text { 37. Bahrain } \\
\text { 38. Hungary } \\
\text { 39. Slovakla } \\
\text { 40. Uruguay } \\
\text { 41. Estonia } \\
\text { 42. Costa Rlca } \\
\text { 43. Chile } \\
\text { 44. Qatar } \\
\text { 45. Lithuania } \\
\text { 46. Kuwait } \\
\text { 47. Croatia } \\
\text { 48. United Arab Emirates } \\
\text { 49. Bahamas } \\
\text { 50. Latvla } \\
\text { 51. Salnt Kitts and Nevls } \\
\text { 52. Cuba } \\
\text { 53. Belarus } \\
\text { 54. Tinidad and Tobago } \\
\text { 55. Mexico } \\
\text { (SAR) }\end{array}$ & 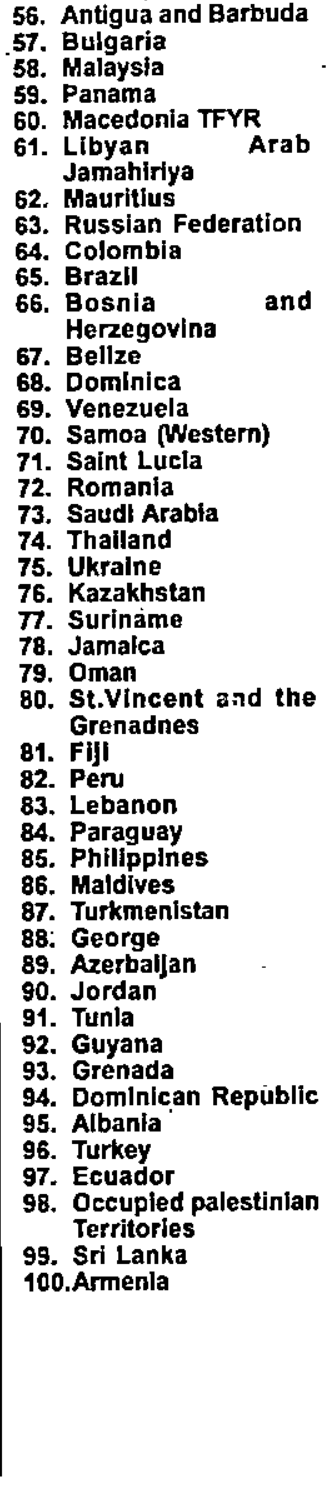 & 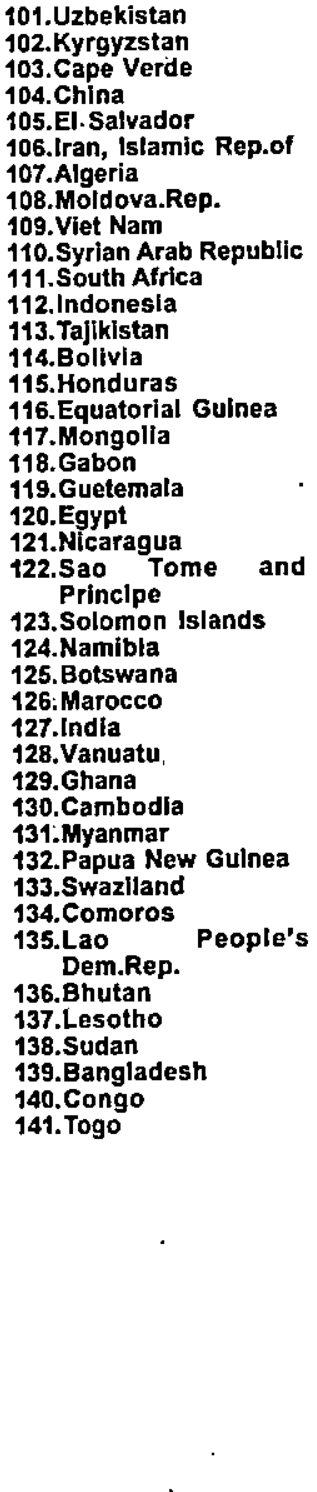 & $\begin{array}{l}\text { 142. Cameroon } \\
\text { 143. Nepal } \\
\text { 144.Pakistan } \\
\text { 145.Zimbabwe } \\
\text { 146. Kenya } \\
\text { 147. Uganda } \\
\text { 148. Yemen } \\
\text { 149. Madagascar } \\
\text { 150. Haiti } \\
\text { 151. Gambla } \\
\text { 152. Nigeria } \\
\text { 153. Djibouti } \\
\text { 154. Mauritania } \\
\text { 155. Eritrea } \\
\text { 156.Senegal } \\
\text { 157. Guinea } \\
\text { 158.Rwanda } \\
\text { 159.Benin } \\
\text { 160. Tanzania, Rep. of } \\
\text { 161. Cote d'lvoire } \\
\text { 162. Malawi } \\
\text { 163.Zambla } \\
\text { 164.Angola } \\
\text { 165.Chad } \\
\text { 166. Guinea-Bissau } \\
\text { 167. Congo Dem.Rep.of } \\
\text { the } \\
\text { 168. Central African Re- } \\
\text { public } \\
\text { 169. Ethiopla } \\
\text { 170. Mozambique } \\
\text { 171. Burundi } \\
\text { 172. Mali } \\
\text { 173. Burkina Faso } \\
\text { 174. Niger } \\
\text { 175.Sierra Leone }\end{array}$ \\
\hline
\end{tabular}

Sumber: UNDP (2003) .

tinggi, tingkat kematian bayi yang rendah, dan tingkat kesenjangan dan kemiskinan yang rendah memberikan sumbangan positif terhadap pertumbuhan ekonomi yang cepat

di Asia Timur dan di Asia Tenggara. ${ }^{7}$ Kajian Lucas (1988) dan juga Easterly dan Levine ${ }^{9}$

\footnotetext{
${ }^{7}$ Kuncoro 2002 hal. 53
} 
Topik: Kepemimpinan Nasional Pasca Pemilu 2004

\section{Tabel 3. Pengeluaran Publik untuk Kesehatan dan Pendidikan di Beberapa Negara Asia}

\begin{tabular}{|l|c|c|}
\hline \multirow{2}{*}{ N e g a r a } & \multicolumn{2}{c|}{ Pengeluaran } \\
\cline { 2 - 3 } \multicolumn{1}{c|}{ Indonesia } & Pendidikan (\% dr GNP 1997) & Kesehatan (\% dr GDP 1996-98) \\
\hline China & 1,4 & 0,6 \\
\hline Singapura & 2,3 & 0,7 \\
\hline Filipina & 3,0 & 1,1 \\
\hline Korea Selatan & 3,4 & 1,7 \\
\hline Thailand & 3,7 & 2,5 \\
\hline Malaysia & 3,8 & 1,7 \\
\hline Bangladesh & $, 4,9$ & 1,3 \\
\hline Pakistan & 2,2 & 1,6 \\
\hline India & 2,7 & 0,8 \\
\hline Nepal & 3,2 & 0,6 \\
\hline Sri Lanka & 3,2 & 1,3 \\
\hline
\end{tabular}

Sumber: Diolah dari UNSFIR, 2000

menunjukkan variabel pendidikan, yang dilihat dari rata-rata lamanya sekolah, secara langsung mempengaruhi pertumbuhan ekonomi. Di negara maju, investasi pada sumber daya manusia juga merupakan sumber utama pertumbuhan ekonomi (Meier, 1995: 313). Oleh karena itu, pemerintahan baru nantinya memberikan perhatian pada aspek pembangunan manusia ini.

Keterkaitan pembangunan manusia dengan pertumbuhan ekonomi (dan juga dengan pembangunan demokrasi) tampaknya tidak lagi diperdebatkan, baik secara icoritik maupun dukungan data empirik. Namun demikian, dalam hal proses dan variabel penyebab (indepedent variable) terjadinya pertumbuhan ekonomi tersebut, masih terdapat beberapa perbedaan pandangan dan menjadi perdebatan akademik para peneliti. Sebagaimana dilaporkan BPS-Bappenas-UNDP (2001:2526) dan Kuncoro (2002:52-57), terdapat beberapa varian pandangan yang didukung oleh studi empirik tentang keterkaitan pembangunan manusia dengan pertumbuhan ekonomi. Namun demikian ini.tidak memperkecil arti pentingnya pembangunan sumber daya manusia tersebut. Artinya, harus ada usaha yang sungguh-sungguh untuk meningkatkan kualitas sumber daya manusia tersebut.

\section{Penutup}

Uraian di atas memberikan gambaran bahwa sangat banyak masalah besar dalam bidang ekonomi yang harus dijawab oleh rezim pemerintahan 2004-2009 di Indonesia. Persoalan-persoalan tersebut memang tidak mungkin diselesaikan dalam tempo satu periode pemerintahan saja atau hanya dalam lima tahun. Oleh karena itu, yang diperlukan dari rezim pemerintahan tersebut

${ }^{8}$ Easterly, William, dan Ross Levine, "It is Not Factor Accumulation: Stylized Facts and Growth Model", dalam The Wortd Bank Economic Review; Oxford University Press, Cary, NC 2001. 
Masalah Utama Ekonomi Indonesia: Tantangan bagi Rezim ..., Edy Suandi Hamid

adalah kejelasan agendanya, yang secara terencana dan tejadwal bisa menunjukkan rencana kerja dengan target-target yang jelas dan terukur. Misalnya, untuk mengurangi pengangguran, program apa yang akan dilakukan selama lima tahun ke depan, dan berapa banyak jumlah penganggur yang bisa diserap bursa kerja. Dengan demikian, publik pun bisa menilai kinerja pemerintahan secara obyektif. 0

\section{Daftar Pustaka}

Badan Pusat Statistik, BAPPENAS, dan UNDP, 2001, Indonesia Human Development Report 2001 - Towards a New Consensus:- Democracy and Human Development in Indonesia, Jakarta:BPS, BAPPENAS, dan UNDP

Basri, Chatib, 2004, " Paradoks Platform Ekonomi Partai Politik",8 Maret 2004, Jakarta:Kompas.

Easterly, William, dan Ross Levine, 2001, "It is Not Factor Accumulation: Stylized Facts and Growth Model", dalam The World Bank Economic Review, Cary, NC: Oxford University Press.

Habibi, Nadir et.al, 2001, "Decentralization in Argentina", Economic Growth Center Discussion Paper Series, Paper No. 525, New Heaven:Economic Growth Center Yale University

Hamid, Edy Suandj 2003, "Ketimpangan Fiskal Vertikal dan Formula Alternatif Dana Alokasi Umum" disertasi pada Program Studi Ilmu Ekonomi Pasca Sarjana UGM, Yogyakarta: Pascasarjana UGM.
Hamid, Edy Suandi, 2003, "Ekonomi-Politik 2004", Makalah dalam Seminar tentang Agenda Ekonomi Partai Politik, Yogyakarta: UAD

Hamid, Edy Suandi, 2003, "Penanggulangan Kemiskinan dan Ekonomi Rakyat", Makalah dalam Forum Kajian tentang Penanggulangan Kemiskinan dan Ekonomi Rakyat yang diadakan Badan Informasi Daerah Yogyarakta Yogyakarta: tanggal 25 Oktober 2003.

Mubyarto, 2003, Ekonomi Pancasila: Renungan Satu Tahun Pustep UGM, Indonesia, Yogyakarta:PUSTEP UGM.

Mubyarto, 2004, Teknokrat dan Ekonomi Pancasila, Yogyakarta: PUSTEP UGM.

Rowter, Kahlil, "Tantangan Kebijakan Ekonomi Pemerintahan Baru", 16 April 2004, Jakarta:Kompas.

Todaro, Michael, 2000, Economic Development. edisi ketujuh,England: Addison-Wesley.

UNDP, 2003, Human Development Report, 2003, New York:Oxford University Press

UNSFIR (United Nations Support Facility for indonesian Recovery), 2000, Indonesia: The National Human Development Report 2000, Jakarta:UNSFIR 